\begin{abstract}
ARTICLES
THE INTERNATIONAL CONTRACTING PRACTICES SURVEY PROJECT: AN EMPIRICAL STUDY OF THE VALUE AND UTILITY OF THE UNITED NATIONS CONVENTION ON THE INTERNATIONAL SALE OF GOODS (CISG) AND THE UNIDROIT PRINCIPLES OF INTERNATIONAL COMMERCIAL CONTRACTS TO PRACTITIONERS, JURISTS, AND LEGAL ACADEMICS IN THE UNITED STATES
\end{abstract}

Peter L. Fitzgerald*

\title{
INTRODUCTION
}

In an era of globalization it is perplexing that so many U.S. practitioners, jurists, and legal academics continue to view contract issues as governed exclusively by state common law and the Uniform Commercial Code. In essence, a significant number of lawyers may be defaulting to the wrong law, in the absence of an effective choice of law clause, when trying to determine the rights and responsibilities arising out of international commercial transactions. The object of the International Commercial Contracting Practices Survey Project was to learn more about how and why this occurs.

The United Nations Convention on Contracts for the International Sale of Goods ("CISG") ${ }^{1}$ and the UNIDROIT Principles of International \footnotetext{
Florida.

(C) 2008 Peter L. Fitzgerald, Professor of Law, Stetson University College of Law, Gulfport,

1. The CISG was promulgated in 1980 by the UN Commission for International Trade Law ("UNCITRAL"), and is sometimes also referred to as either the UNCITRAL or Vienna Convention on the International Sale of Goods. United Nations Convention on Contracts for the International Sale of Goods,
} 
Commercial Contracts ${ }^{2}$ are examples of two significant international instruments that are relied upon much more often by those dealing in commercial transactions outside of the country than by those here in the United States. Apart from anecdotal discussion, there has been relatively little examination of why this is the case. ${ }^{3}$ Accordingly, the aim of the survey was to assess and document current opinions of U.S. practitioners, jurists, and legal academics regarding the value and utility of these instruments, two decades after the U.S. ratified the CISG, ${ }^{4}$ and more than a decade after the promulgation of the UNIDROIT principles.

The CISG provides a comprehensive set of default legal rules governing contract formation, the obligations of buyers and sellers, remedies for breach, and a variety of other aspects of international commercial contracts for the sale of goods, and therefore overlaps with a large part of the coverage of Article 2 of the Uniform Commercial Code ("UCC") in the U.S. ${ }^{5}$ Seventy-one countries are contracting parties to the Convention. These include the United States and, with the exception of the United Kingdom, virtually all of the world's major trading nations. ${ }^{6}$ Nevertheless, after nearly twenty years of

Apr. 11, 1980, S. Treaty Doc. No. 98-99 (1983), 1489 U.N.T.S. 3, available at http://www.uncitral.org/ pdf/english/texts/sales/cisg/CISG.pdf.

2. The UNIDROIT Principles were first issued in 1994 and updated in 2004. InTERNATIONAL Institute for the Unification of Private Law, UNIDROIT Principles of International COMMERCIAL CONTRACTS (2004), available at http://www.UNIDROIT.org/english/principles/contracts/ main.htm.

3. Professor Michael Gordon, at the University of Florida, conducted an earlier study of attitudes towards the CISG and the UNIDROIT Principles among members of the Florida bar, judiciary and academia a decade ago, which was one of the first attempts to assess and document the use of these instruments in this country. M.W. Gordon, Some Thoughts on the Receptiveness of Contracts Rules in the CISG and UNIDROIT Principles as Reflected in One State's (Florida) Experience of (1) Law School Faculty, (2) Members of the Bar with an International Practice, and (3) Judges, 46 Ам. J. CомP. L. 361 (1998). Other papers which touch upon the U.S. experience with these instruments include W.S. Dodge, Teaching the CISG in Contracts, 50 J. Legal Educ. 72, $74-78$ (2000); M.F. Koehler \& G. Yujun, The Acceptance of the Unified Sales Law (CISG) in Different Legal Systems-An International Comparison of Three Surveys on the Exclusion of the CISG'S Application Conducted in the United States, Germany, and China, 20 PACE INT'L L. REV. (forthcoming 2008); G. Philippopoulos, Awareness of the CISG Among American Attorneys, 40 UCC L.J. 357 (2008); C.S. Sukurs, Harmonizing the Battle of the Forms: a Comparison of the United States, Canada, and the United Nations Convention on Contracts for the International Sale of Goods, 34 VAnd. J. TRAnSNAT'L L. 1481, 1511-15 (2001); and J. Ziegel, The Scope of the Convention: Reaching Out to Article One and Beyond, 25 J.L. \& CoM. 59, 67-71 (2005).

4. The United States ratified the Convention in 1986, and the CISG entered into force on January 1 , 1988. See CISG_Status, http://www.uncitral.org/uncitral/en/uncitral_texts/sale_goods/1980CISG_ status.html.

5. See generally CISG, supra note 1; L.F. Del Duca \& P. Del Duca, Selected Topics Under the Convention on International Sale of Goods (CISG), 106 Dick. L. REv. 205 (2001).

6. See Unilex Info, List of CISG Contracting States, http://www.unilex.info/dynasite.cfm? 
experience, the CISG is rarely seen and perhaps even less frequently understood by those engaged in commercial transactions in this country, despite being as much a part of our domestic law as is the UCC. By one count, the CISG appears in only fifty-six reported cases in the United States, ${ }^{7}$ but figures much more prominently in judicial and arbitral decisions elsewhere around the world. ${ }^{8}$ This is particularly the case with China, which is this nation's second largest trading partner right behind Canada. ${ }^{9}$

The UNIDROIT Principles of International Commercial Contracts, promulgated by the International Institute for the Unification of Private Law, ${ }^{10}$ are intended to reflect generally accepted aspects of commercial contract law drawn from a variety of different legal systems, and to function much like an international equivalent of the American Law Institute's Restatement of the Law of Contracts. ${ }^{11}$ However, in addition to serving as a guide to contract interpretation, the Principles have also become important as a model for the domestic law of several countries. ${ }^{12}$ In the United States, however, the

dssid $=2376 \&$ dsmid $=13351 \& x=1$. In addition to the United Kingdom, Japan was the other major trading country that had long declined becoming a contracting party to the CISG. However, Japan's accession to the CISG is reportedly imminent, and may occur by the end of 2008. See H. Sono, Contract Law Harmonization and Non-Contracting States: The Case of the CISG, 2-3 (2007), available at http://www.uncitral.org/pdf/english/congress/Sono_hiroo.pdf.

7. See Unilex Info, List of CISG Cases by Country-United States, http://www.unilex.info/ cases.cfm?pid=1\&do=Country\&cr=27\#A649. Other databases, such as Westlaw or Lexis, report a slightly higher number of cases involving the CISG, with fewer than 60 cases involving the CISG in U.S. courts. See also CISG Database, Country Case Schedule-United States, http://www.cisg.law.pace.edu/ $\mathrm{cisg/text/casecit.html \# us} \mathrm{(listing} 96$ such cases). Professor Ziegel suggests that a similar situation exists in other common law countries as well. Ziegel, supra note 3, at 67-72.

8. Use of the CISG is becoming particularly common in cases and arbitral decisions in both China and Russia. One commentator identified 320 cases from the People's Republic of China that involved the CISG, 268 of which were arbitral decisions before the China International; Economic and Trade Arbitration Commission (CIETAC). F. Yang, CISG in China and Beyond, 40 UCC L.J. 373, 375 (2008). Interestingly, 74 of these CIETAC decisions involved U.S. parties. Id. See also Ziegel, supra note 3, at 72; D. Saidov, Cases on CISG Decided in the Russian Federation, 7 Vindobona J. InT'L \& Comp. L. 1 (2003); and F. Yang, The Application of the CISG the Current PRC Law and CIETAC Arbitration Practice, 2 NORDIC J. Commercial L. 1 (2006), available at http://www.njcl.utu.fi/2_2006/article4.pdf. See generally CISG Database, Country Case Schedule, available at http://www.cisg.law.pace.edu/cisg/text/casecit.html.

9. See id.; U.S. Census Bureau, Foreign Trade Statistics, Top Trading Partners - Total Trade, Year to Date December, 2007, http:/www.census.gov/foreign-trade/statistics/highlights/top/top0712.html.

10. See UNIDROIT PRINCIPLES, supra note 2. The Institute for the Unification of Private International Law, commonly known by its French name as "UNIDROIT," is an independent intergovernmental institution initially established as an adjunct to the League of Nations.

11. Restatement (Second) of Contracts (1981).

12. See M.J. Bonell, UNIDROIT Principles 2004-The New Edition of the Principles of International Commercial Contracts adopted by the International Institute for the Unification of Private Law, 1 UNIFORM L. ReV. 5, 7-8, 13-17 (2004). 
Principles are perhaps even less familiar than the CISG. The UNIDROIT Principles appear in only one reported case and one arbitral decision in the U.S. ${ }^{13}$

The International Contracting Practices Survey Project expands upon the work of Professor Michael Gordon at the University of Florida, who surveyed attitudes towards these instruments in Florida ten years ago in connection with his report to the XVth International Congress of Comparative Law. ${ }^{14}$ In addition to Florida, this new survey specifically sought responses from four other jurisdictions, including two additional top exporting states, California and New York, and two at the bottom of the U.S. Census Bureau's list of exporting states, Hawaii and Montana. ${ }^{15}$ One reason for targeting these particular jurisdictions, in addition to enlarging the sample area, was to see if there were significant differences in the opinions expressed by those in states with substantial international dealings as compared to those in states with relatively little international trade. ${ }^{16}$ Additionally, while particular emphasis was placed upon obtaining responses from these five target jurisdictions, the survey was open to other participants as well. Accordingly, responses were received from 23 U.S. jurisdictions and 15 foreign countries or regions by the time the survey was closed. ${ }^{17}$

\section{Survey Methodology}

The survey was conducted entirely online, using the Zoomerang online survey hosting service, ${ }^{18}$ although the initial "welcome" page that provided entry to the actual survey was hosted on the Stetson University College of

13. See Unilex Info, List of UNIDROIT Principles Cases by Country-United States, http://www.unilex.info/cases.cfm?pid=2\&do=country\&cr=17\#A41. However it should also be noted that, given the nature of the UNIDROIT Principles, they are arguably more likely to be used in arbitral proceedings than litigation. Moreover, as many arbitral decisions are unpublished, the total number of decisions referring to the Principles in some form is likely to be understated by the figure found in the above-referenced citation, or any other, database.

14. Gordon, supra note 3.

15. See U.S. Census Bureau, Foreign Trade Statistics, U. S. Exports of Goods by State, ZIP Code Based, by NAICS-Based Product Code Groupings, Not Seasonally Adjusted: December 2006 and Cumulative to Date, 2006, http://www.census.gov/foreign-trade/statistics/state/zip/2006/12/zipstate.pdf

16. However, it should be noted that the Census Bureau does not track import data in the same fashion as it tracks export data. Accordingly, Hawaii is in the somewhat anomalous position of having very few exports, and therefore ranking quite low in the government's statistical summary, but obviously being heavily dependent upon imports. Nonetheless, it was felt that it was important to have another West Coast state represented in the survey, and Hawaii has the lowest reported trade volumes of those states. See id.

17. See infra note 29 and accompanying text.

18. Zoomerang Home Page, http://info.zoomerang.com/. 
Law website. While it was recognized that employing an electronic tool could adversely impact a potential respondent's willingness to participate, it was also thought that the converse might be true - that the ability to access and quickly respond to the survey online might result in a greater response from busy practitioners, jurists, and academics than with a hardcopy survey. Moreover, it was assumed that most practitioners and academics, and many judges, would now be much more comfortable with electronic tools, computers, and the Internet than was the case a decade ago. Accordingly, when combined with the ability to cost effectively collect, collate, and analyze the data in an electronic form, the decision was made to use an online tool for this survey project.

Each participant was asked to respond to between 20 and 38 questions, depending upon their responses. There were ten basic questions asked of all participants. ${ }^{19}$ These were followed by questions specifically directed at practitioners, ${ }^{20}$ jurists, ${ }^{21}$ and legal academics. ${ }^{22}$ The online tool would present only the appropriate questions to any individual participant based upon that participant's self-identification as a member of one of these groups. Finally, there was an open ended question for each participant that closed the survey by inviting any other pertinent comments or observations the participants might care to offer. ${ }^{23}$ Apart from declaring one's professional occupation and home jurisdiction, no personally identifiable information was collected from any of the survey participants and all responses remain entirely anonymous.

A variety of means were used to solicit input and encourage participation in the survey project. In order to obtain responses from practitioners, email invitations with links to the online survey were sent to the chairs of both the Business Law and International Law Sections of the bar in each of the five target jurisdictions, with a request that they publicize or redistribute the survey invitation to their membership. ${ }^{24}$ Additional requests were sent to the ABA

19. The ten basic questions asked of all participants are found in Part I of the Appendix, Questions 1-10, infra.

20. The nine additional questions specifically directed to practitioners are found in Part II of the Appendix, Questions 11-19, infra.

21. The eight additional questions specifically directed to judges are found in Part III of the Appendix, Questions 20-27 infra.

22. The seventeen additional questions specifically directed to law professors are found in Part IV of the Appendix, Questions 28-44, infra.

23. The final question asked of all participants is found in Part V of the Appendix, Question 45, infra.

24. In the case of New York, which does not have a unified bar, the invitations were sent to the section chairs of the New York State Bar Association. Additionally, as Montana does not have an International Law Section, their invitations were sent to the Business Law Section and the President of the 
International Law Section and the International Business Law Committee of the ABA Business Law Section. Similar emails and follow-up letters were sent to the court administrators and to the Chief Judge or Chief Justices of the highest courts in California, Florida, Hawaii, Montana, and New York, in an effort to obtain input from members of those states' judiciary, and individual letters were sent to each of the 363 federal District Judges or Magistrates in those states. In order to obtain input from academics, each of the 321 law professors shown as teaching either Contracts or Commercial Law at a school in one of the target jurisdictions in the 2006-2007 AALS Directory of Law Teachers also received an individual email invitation to participate in the survey, and general invitations were posted on the AALS Section on Contracts (AALSCONTRACTS), ${ }^{25}$ the Law Professors and Lecturers (LAWPROF), ${ }^{26}$ and the ASIL International Economic Law Interest Group (ASIL_ECONOMICIG) $^{27}$ email listservs. The CISG/UNIDROIT Principles Survey was opened at the beginning of August 2006, and closed for any further responses at the beginning of May 2007.

\section{Survey Results}

Survey Part I: General Questions Addressed to All Participants

\section{Participants and Background}

A total of 236 individuals responded to the survey, with $66 \%$ of the responses coming from practitioners, $7 \%$ from jurists, and $27 \%$ from legal academics. ${ }^{28}$ The majority of the responses, $68 \%$, came from the five target jurisdictions of California, Florida, Hawaii, Montana, and New York. However, $22 \%$ of the practitioners or academics who responded were located in other U.S. jurisdictions, and 10\% came from foreign jurisdictions. Altogether, responses were received from 22 states, the District of Columbia, and 15 foreign countries or regions. ${ }^{29}$

\footnotetext{
Montana Bar Association.

25. See AALS Section on Contracts - Listserv, http://www.aalscontracts.com/activities/listserv.html.

26. See Chicago-Kent College of Law center for Law and Computers-Mailing List Information, http://www.kentlaw.edu/clc/mailing_lists/listoflists.shtml.

27. See ASIL International Economic Law Interest Group, http://www.asil.org/economiclaw/ index.html.

28. Appendix, Question 1, infra.

29. Among the 75 respondents who stated they were located outside of the five target jurisdictions, 32 practitioners and 18 law professors listed other states in the United States. One law professor simply
} 


\section{Basic Familiarity with the CISG and UNIDROIT Principles}

All the survey participants were asked to complete the ten questions in Part I, which were aimed at generally assessing their basic familiarity with the CISG and the UNIDROIT Principles. Each participant was initially asked to declare whether they considered themselves "thoroughly," "moderately," "somewhat," or "not at all" familiar with both the CISG and the UNIDROIT Principles. Most participants were more aware of the CISG than the UNIDROIT Principles, with $43 \%$ declaring that they felt "thoroughly" or "moderately" familiar with the CISG ${ }^{30}$ whereas only $26 \%$ made the same statements regarding the UNIDROIT Principles. ${ }^{31}$

Law professors claimed the greatest familiarity with both the CISG and the UNIDROIT Principles, with 75\% declaring that they were "thoroughly" or "moderately" familiar with the $\mathrm{CISG}^{32}$ and $43 \%$ similarly familiar with the UNIDROIT Principles. ${ }^{33}$ While the law professors' familiarity with the CISG is comparable to what Professor Gordon observed in 1996, this represents a significant improvement in awareness of the UNIDROIT Principles which were largely unknown at the time of the earlier survey. ${ }^{34}$

U.S. practitioners reported much lower comparable levels of familiarity of $30 \%$ regarding the $\mathrm{CISG}^{35}$ and $17 \%$ regarding the UNIDROIT Principles. ${ }^{36}$ This almost precisely matches what Professor Gordon observed in Florida a decade ago. ${ }^{37}$

declared "I do not practice" and is included among the "Other U.S." respondents throughout these survey results. Together these 51 individuals amount to $22 \%$ of all respondents. A further 21 practitioners and 3 law professors, accounting for $10 \%$ of all respondents, declared that they were located in a foreign country or region. Appendix, Question 2, infra.

30. Appendix, Question 3, infra.

31. Appendix, Question 4, infra.

32. Appendix, Question 3, infra, Response from Law Professors.

33. Appendix, Question 4, infra, Response from Law Professors.

34. Gordon, supra note 3, at 364. Law professors in Florida in the current survey expressed even higher levels of familiarity with both the CISG and the UNIDROIT Principles. Among legal academics in Florida 93\% said they were "thoroughly" or "moderately" familiar with the CISG, and 57\% were similarly familiar with the Principles. Appendix, Question 4, infra, Response from Law Professors in Florida.

35. Appendix, Question 3, infra, Response from Practitioners. This figure increases to $34 \%$ if the survey responses from foreign practitioners are also considered. Id.

36. Appendix, Question 4, infra, Response from Practitioners. This figure increases to $20 \%$ if the survey responses from foreign practitioners are also considered. Id.

37. Gordon, supra note 3, at 368. However, practitioners in Florida in the current survey reported significantly higher levels of familiarity with the CISG, and to a lesser degree also with the UNIDROIT Principles than what Professor Gordon observed. Among practitioners in Florida 71\% reported they were 
Also, much as Professor Gordon found, ${ }^{38}$ the judiciary was at the other end of the scale, with $82 \%$ declaring that they were "not at all familiar" with the $\mathrm{CISG}^{39}{ }^{39}$ and $88 \%$ declaring they were similarly unfamiliar with the UNIDROIT Principles. ${ }^{40}$

Comparing the responses from California, Florida, and New York, with those obtained from Hawaii and Montana, shows a striking difference in the reported levels of awareness of these instruments among the practitioners. Only a single practitioner in the low exporting states indicated even a "moderate" level of familiarity with the CISG and the UNIDROIT Principles, as compared to the 26 who were familiar with the CISG or the 13 who were familiar with the Principles in the top exporting states. ${ }^{41}$

These responses suggest that the CISG, in particular, continues to be misperceived as a "foreign law" and of relatively little concern to U.S. practitioners and judges. Other commentators have anecdotally observed this manifested in two respects, either in a tendency to view the CISG as not being part of the contract law of the United States at all, or as being confined to federal law and of concern only in large international commercial contracts. ${ }^{42}$ Comments from two of the survey participants further illustrate these attitudes. A practitioner in Montana wrote:

Some uniform international standards for contracts are probably important; however, U.S. law should govern contracts performed in the United States. Our laws tend to be fair

"thoroughly" or "moderately" familiar with the CISG, and 36\% were similarly familiar with the Principles. Appendix, Question 4, infra, Response from Practitioners in Florida.

38. Gordon, supra note 3, at 369-70. At the time of Professor Gordon's survey, there were no reported cases in Florida that involved either the CISG or the UNIDROIT Principles, and virtually all of the judges who responded were ignorant of these instruments.

39. Appendix, Question 3, infra, Response from the Judiciary.

40. Appendix, Question 4, infra, Response from the Judiciary.

41. See Appendix, Questions 3 and 4, infra, Response from Practitioners.

42. See Martin F. Koehler, Survey Regarding the Relevance of the United Nations Convention for the International Sale of Goods (CISG) in Legal Practice and the Exclusion of its Application (Oct. 2006), http://cisgw3.law.pace.edu/cisg/biblio/koehler.html. Koehler examined the reasons offered by 81 German and American practitioners for excluding the application of the CISG from international contracts. Several comments Koehler received from American lawyers in response to his survey were to the effect that their clients could not be dissuaded from application of "national" law because their companies were unfamiliar with the CISG. See also Gordon, supra note 3, at 363. Professor Gordon reports on a judge in Miami who refused to believe the U.S. signed a treaty that could supersede the state's adoption of the UCC, and another judge in Tampa who similarly indicated that while the CISG might be intended to apply in federal courts, he would not apply it in his court. See also V. Susanne Cook, The U.N. Convention on Contracts for the International Sale of Goods: A Mandate to Abandon Legal Ethnocentricity, 16 J.L. \& CoM. 257 (1997). 
with appropriate recourse for all parties involved. We should not be so willing to place this responsibility in the hands of an international body. ${ }^{43}$

Another practitioner from one of the top exporting states, New York, similarly opined: "I am not sure the country is ready to surrender states' rights sufficiently to warrant accepting an international convention, except with multinational entities." ${ }^{\prime 4}$ Both of these views are seriously mistaken, but nonetheless notable twenty years after the U.S. ratification of the CISG. The CISG is part of the domestic law of contracts in every state in the United States, fully applicable by its own terms, and therefore provides the default legal rules applicable to international transactions between businesses located in countries that are party to the Convention. ${ }^{45}$

\section{Background and Training in CISG and UNIDROIT Principles}

Two-thirds of the survey participants who claimed some degree of familiarity with either the CISG or the UNIDROIT Principles indicated they gained that knowledge through individual research in books, law journals, or professional magazines. Formal law school courses came in a distant second as a source of that knowledge, identified by only $29 \%$ of the respondents, followed by $23 \%$ who gained their familiarity with these instruments through online research in sources other than Westlaw or Lexis. ${ }^{46}$ Participation in litigation or arbitral proceedings was also an important source of learning for

43. Appendix, Question 45, infra, Response from Practitioners.

44. Id.

45. See CISG supra note 1, Article 1, which reads:

(1) This Convention applies to contracts of sale of goods between parties whose places of business are in different States:

(a) when the States are Contracting States; or

(b) when the rules of private international law lead to the application of the law of a Contracting State.

(2) The fact that the parties have their places of business in different States is to be disregarded whenever this fact does not appear either from the contract or from any dealings between, or from information disclosed by, the parties at any time before or at the conclusion of the contract.

(3) Neither the nationality of the parties nor the civil or commercial character of the parties or of the contract is to be taken into consideration in determining the application of this Convention. See also Asante Technologies, Inc. v. PMC-Sierra, Inc., 164 F. Supp. 2d 1142, 1147 (N.D. Cal. 2001).

The suspicion if not outright hostility towards the CISG reflected in these respondents' comments is not confined just to practitioners. In one of the very early U.S. decisions involving the Convention, U.S. District Judge Brieant wrote that "the State Department undertook to fix something that was not broken by helping to create the Sale of Goods Convention which varies from the Uniform Commercial Code in many significant ways.” Filanto, S.p.A. v. Chilewich Int'l Corp., 789 F. Supp. 1229, 1238 (S.D.N.Y. 1992).

46. Appendix, Question 5, infra. 
practitioners and legal academics and, as would be expected, the predominant source of information for U.S. jurists. ${ }^{47}$ Continuing legal education programs were the least common source of information identified by practitioners and academics. $^{48}$

However, $72 \%$ of the survey participants indicated that the CISG should be taught in CLE programs, $66 \%$ thought it should be included in advanced law school courses, $50 \%$ thought it should be covered in basic law school Contracts or Sales courses, and 37\% advocated specialized training for the judiciary. Only $6 \%$ of the respondents felt that additional formal training or education regarding the CISG was unnecessary. ${ }^{49}$

As a group, law professors were the strongest advocates of additional formal education regarding the CISG, with $78 \%$ supporting its inclusion in advanced law school courses, and $67 \%$ in favor of addressing the CISG in a basic Contracts or Sales course. Three quarters of the law professors also favored including the CISG in CLE programs, and 59\% supported its inclusion in specialized training programs for the judiciary. Interestingly, three of the professors responding to this question, $5 \%$ of the total, were among those who felt no additional education on the CISG was necessary at this time. ${ }^{50}$

Practitioners were similarly in favor of increased formal training, $62 \%$ indicating the CISG should be part of advanced law school courses, with $43 \%$ of U.S. practitioners - and $69 \%$ of the foreign practitioners responding - urging that it be addressed in basic law school courses. Furthermore, $72 \%$ of practitioners wanted to see the CISG covered in CLE programs, and more than a quarter recommended it for specialized training for the judiciary. ${ }^{51}$

The judiciary was also generally supportive of additional formal training in the CISG, with 50\% supporting its inclusion in advanced law school courses, $30 \%$ supporting addressing the CISG in basic Contracts or Sales courses, $60 \%$ suggesting it was an appropriate subject for CLE programs, and $30 \%$ of the judges wanting to see the CISG included in specialized training for the judiciary. ${ }^{52}$

The responses indicated a similar pattern advocating addressing the UNIDROIT Principles in both advanced law school courses and CLE

47. Id. Responses from Practitioners, the Judiciary, and Law Professors.

48. Id.

49. Appendix, Question 6, infra.

50. Id.; Responses from Law Professors.

51. Id.; Responses from Practitioners.

52. Id.; Response from the Judiciary. 
programs, and to a lesser degree in basic Contracts or Sales courses and specialized training programs for the judiciary, albeit with lower levels of support. Two-thirds of the respondents indicated the UNIDROIT Principles should be addressed in advanced law school courses, 63\% supported their inclusion in CLE programs, $35 \%$ in basic law school courses, and $26 \%$ in specialized training programs for the judiciary. The number of those who felt additional formal education in the UNIDROIT Principles was unnecessary at this time was $10 \%$, or nearly double that seen with regard to the CISG. ${ }^{53}$ As with the similar question regarding the CISG, however, legal academics and foreign practitioners were again the leading proponents of further formal education regarding the UNIDROIT Principles. ${ }^{54}$

\section{Interpretation of "Choice of Law" Clause Invoking the CISG}

Each of the survey participants was then asked to interpret the meaning of a choice of law clause in an international commercial sales contract between parties in different CISG signatory states which read, "the law of (insert name of your jurisdiction) shall apply."

While $48 \%$ said that meant the CISG would apply to the contract as part of the law of their jurisdiction, $40 \%$ of the respondents indicated that the UCC would either apply in lieu of, or prevail over, the application of the CISG. ${ }^{55}$ This is roughly comparable to what Professor Gordon found with a similar query to Florida practitioners in his 1996 survey. ${ }^{56}$

This result does not appear to be substantially affected by the volume of export related activity in the respondents' jurisdiction. Only $50 \%$ of practitioners in California, 53\% in Florida, and 28\% in New York-all high volume exporting states - selected the CISG as the applicable law in this question. In the low volume exporting states, $40 \%$ of the practitioners in Hawaii and $25 \%$ of the practitioners in Montana similarly selected the CISG as the applicable law. In comparison $62 \%$ of the foreign practitioners selected the CISG as the applicable law. ${ }^{57}$

The judiciary's response to this question, however, was different from a decade ago. In Professor Gordon's survey $90 \%$ of the judges would apply the

53. Appendix, Question 7, infra.

54. See id., Response from Practitioners and Law Professors.

55. Appendix, Question 8, infra.

56. Gordon, supra note 3, at 368-69.

57. Appendix, Question 8, infra, Response from Practitioners. 
UCC when presented with such a clause,$^{58}$ whereas only $36 \%$ of the judges responding to the current survey would apply the UCC in lieu of the CISG in such a case, and $18 \%$ affirmatively selected the CISG as the law governing such a contract. ${ }^{59}$

Among law professors, 59\% identified the CISG as the applicable law, but $39 \%$ of all law professors - including $29 \%$ of those in California, $21 \%$ of those in Florida, and $45 \%$ of those in New York-believed the UCC would either apply or prevail in the event of any inconsistency with the CISG. ${ }^{60}$

None of these results are particularly encouraging. While CISG Article 6 does permit the parties to derogate from any part of the Convention, or to exclude the application of the Convention altogether, ${ }^{61}$ the CISG is a selfexecuting treaty and therefore part of the domestic law of the United States. Simply choosing the law of a particular state in a choice of law clause should not act as an implied exclusion of the CISG. ${ }^{62}$ Moreover, as a treaty, the CISG prevails over any inconsistent state law, such as the UCC, as a matter of federal preemption under the supremacy clause of the Constitution. ${ }^{63}$ As Professor Ralph Folsom advises, "if the parties decide to exclude the Convention, it should be expressly excluded by language which states that it [the CISG] does not apply and also [affirmatively] states what law shall govern the contract." ${ }^{\prime 4}$

Accordingly, it would appear that a substantial number of the survey participants are as unclear as to the actual scope and application of the CISG

58. Gordon, supra note 3, at 370.

59. Appendix, Question 8, infra, Response from the Judiciary. However, it should also be noted that the response rate by the judiciary to some of the survey questions, such as this one, are quite low. In part this may reflect a concern several judges expressed as to whether portions of the survey posed issues regarding their obligation to refrain from providing advisory opinions. See infra notes 93-96 and accompanying text.

60. Appendix, Question 8, infra, Responses from Law Professors.

61. See CISG, supra note 1, Arts. 6 and 12. Article 6 provides that "[t]he parties may exclude the application of this Convention or, subject to article 12, derogate from or vary the effect of any of its provisions." Article 12 provides each contracting state with the ability to make reservations to certain provisions of the CISG and still remain a party to the Convention.

62. Asante Technologies, Inc. v. PMC-Sierra, Inc., 164 F. Supp. 2d 1142 (N.D. Cal. 2001); BP Oil Int'l v. Empresa Estatal Petroleos de Ecuador, 332 F.3d 333, 337 (5th Cir. 2003); Valero Mktg. v. Greeni Oy, 373 F. Supp. 2d 475, 482 (D.N.J. 2005); Am. Mint LLC v. GOSoftware, Inc., C.A. No. 1:05-CV-650, 2006 WL 42090, at*3 (M.D. Pa. Jan. 6, 2006). But see Am. Biophysics v. Dubois Marine Specialties, 411 F. Supp. 2d 61 (D.R.I. 2006).

63. U.S. Const., art. VI, cl. 2.

64. Ralph Folsom, 1 International Business Transactions $\S 1.5$ (2d ed. 2007). Professor Folsom goes on to suggest, as an example, "This contract shall not be governed by the United Nations Convention on Contracts for the International Sale of Goods, 1980, but shall be governed by the New York Uniform Commercial Code for domestic sales of goods and other New York Laws." Id. 
as they were a decade ago. This also shows the persistent adverse effect of the misconception of the CISG as a distinctly "foreign" body of law rather than an integral part of our domestic contract law.

Interpretation of "Choice of Law" Clause Invoking the UNIDROIT Principles

The final two questions in Part I attempted to similarly explore the meaning of a contract clause which read "this contract will be governed by the UNIDROIT Principles" both in the context of litigation and in an arbitral proceeding. Given the nature of the UNIDROIT Principles as something akin to an international restatement of the law rather than as a collection of hard legal rules, and the lack of U.S. case law involving the Principles, whether such a clause represents an "a-national" choice of law or is simply a reference to the lex mercatoria or general principles of law is a much more open question.

More than a third of the survey participants felt that the inclusion of such a clause means that in any litigation over the parties' contractual rights, those rights would be determined solely by the UNIDROIT Principles except to the extent that the Principles were inconsistent with the mandatory law of the forum in which the case was heard.$^{65}$ However, $21 \%$ believed that applicable, non-mandatory, national or state law would still apply, as modified by the UNIDROIT Principles. An equal number, 17\%, were at either end of the spectrum, believing either that the parties successfully invoked the exclusive application of the UNIDROIT Principles, or that the parties had completely failed to make any effective choice of law. Only $11 \%$ would interpret such a clause as calling for the use of the Principles to simply supplement or explain the otherwise applicable national or state law. ${ }^{66}$

Asking the same question in the context of an arbitral proceeding produced much the same results, but with a higher general level of support for each option. ${ }^{67}$ However, the law professors were significantly less willing to declare the clause ineffective in an arbitration proceeding than in litigation, ${ }^{68}$

65. Appendix, Question 9, infra. However, more judges (27\%) than practitioners (19\%) or academics $(10 \%)$ were willing to find that such a clause calls for the exclusive application of the UNIDROIT Principles to the parties' obligations. Id.

66. Id.

67. Appendix, Question 10, infra.

68. Only $5 \%$ of law professors would declare such a clause ineffective in the context of arbitration versus $16 \%$ in the context of litigation. Compare Appendix, Question 10, infra, Response from Law Professors, with Appendix, Question 9, infra, Response from Law Professors. 
and the judges were marginally more willing to look exclusively to the UNIDROIT Principles for their decisional rules when dealing with arbitration. ${ }^{69}$

\section{Survey Part II: Questions Addressed to Practitioners}

Each of the practitioners was then asked to respond to a number of questions aimed at examining their actual use of the CISG and the UNIDROIT Principles and their perception of the utility of these instruments.

\section{Addressing the CISG in Contracts}

When drafting international commercial contracts, $55 \%$ of U.S. practitioners who said they were familiar with the CISG specifically choose to opt out of its coverage, while $24 \%$ specifically opt in to the CISG in whole or in part. However, $21 \%$ do not address the Convention at all in their agreements. $^{70}$ This is consistent with other studies that found a comparable, or even higher, tendency for U.S. practitioners to opt out of the CISG in whole or in part. ${ }^{71}$

While the clear trend was to generally opt out of the CISG, practitioners in both California and Montana indicated they were more likely to opt into the Convention's coverage (at least in part) than to opt out, so again the relative amount of export related business conducted in a given jurisdiction does not appear determinative of the approach taken. ${ }^{72}$ Interestingly, only $12 \%$ of practitioners indicated that they had argued for, and 3\% argued against, the

69. In the context of arbitration $30 \%$ of jurists would look exclusively to the UNIDROIT Principles to decide the case under such a clause versus $27 \%$ who would do so in the context of litigation. Compare Appendix, Question 10, infra, Response from Judiciary, with Appendix, Question 9, infra, Response from Judiciary.

70. These figures are based upon the 47 U.S. respondents who addressed the substance of this question. Another 43 U.S. survey participants said that this particular question was not applicable to their practice. See Appendix, Question 11, infra.

71. See, e.g., Koehler, supra note 42 , at 2 . More than $70 \%$ of U.S. respondents in Koehler's survey said they routinely excluded the CISG in their contracts. Id.

72. Only 1 of 4 respondents in California would completely opt out of the Convention's coverage, and the sole respondent from Montana who addressed the substance of this question indicated he or she specifically opts into the CISG. In both Florida and New York the majority of respondents would opt out of the Convention's coverage, and there was no substantive response to this question from practitioners in Hawaii. See Appendix, Question 11, infra. Comparable responses were reported by foreign practitioners, with $56 \%$ of the 16 foreign survey participants who addressed the substance of the question reporting that they opt out of the CISG, $25 \%$ indicating that they opt into the Convention in whole or in part, and $19 \%$ stating they make no reference to the CISG at all in their contractual documents. See id. 
application of the CISG as the default body of law governing the transaction when litigating or arbitrating cases where the parties' contractual documents were completely silent as to the Convention's coverage. ${ }^{73}$

A general preference for the UCC was cited by $33 \%$ of the U.S. participants for choosing to opt out of the CISG, followed by $31 \%$ who indicated client preferences or desires motivated their decision, and $16 \%$ cited their own lack of familiarity with the CISG as the reason for opting out of its coverage. ${ }^{74}$ While $20 \%$ indicated that they would opt out of the CISG because of concerns over specific provisions ${ }^{75}$ when asked to detail those specific concerns a strong generalized preference for the UCC (or other national law) was still evident, rather than particularized concerns over the CISG. ${ }^{76}$ For example, one participant simply indicated they wanted the "home field advantage" of "Florida law," 77 which goes back to the continuing confusion over the status of the CISG in our national law. ${ }^{78}$ This is not just an issue for U.S. practitioners, as another respondent explained that they "prefer to have the laws of Ontario and Canada govern" their commercial contracts, even though Canada-like the U.S.- is also a contracting party to the CISG. ${ }^{79}$

73. See Appendix, Question 15, infra. By a 2:1 margin the California practitioners indicated that they would argue for the CISG's application as the default law for the transaction when the parties' documents did not contain an effective choice of law clause. See id. This is in line with the other survey results which showed that $75 \%$ of practitioners in California would be likely to affirmatively opt into the CISG's coverage. See supra note 72 and accompanying text. The two practitioners in Florida who responded to the substance of this question also declared that they argued for the application of the CISG when the parties' documents did not contain an effective choice of law clause. See Appendix, Question 15, infra. This despite the fact that the majority of Florida's practitioners said they would typically opt out of the CISG's coverage when drafting contracts. See supra note 72 and accompanying text.

74. These figures are based upon the 45 U.S. respondents who addressed the substance of this question. Another 43 U.S. survey participants said that this particular question was not applicable to their practice. See Appendix, Question 12, infra. One California practitioner criticized the premise and structure of this question, explaining that his or her decision to opt in or out of the CISG's coverage was made on a case-by-case basis. Another practitioner - outside of the five target jurisdictions - offered the equally meritorious observation that "internal legal department and contract managers are looking for consistency in . . . their contracts. . . They do not have the time . . . to try to determine whether the CISG and UNIDROIT principles might actually be favorable in a particular situation." Appendix, Question 45, infra, Response from Practitioners.

75. Appendix, Questions 12 and 45, infra.

76. For example, one respondent said that their clients" "basic understanding of the UCC carried the day" and that "no specific provision of the CISG was determinative of this decision." Appendix, Question 13, infra.

77. Id.

78. See supra notes 61-64 and accompanying text.

79. Appendix, Question 13, infra. 
Those who did identify specific issues that prompted their decision to opt out of the CISG listed a mix of factors, some of which are associated with the Convention itself but also several that are more properly associated with other elements of national law. These included the timing of the "meeting of the minds" and the negotiating processes, warranty exclusions, limitation periods, and the role of gap fillers, and the relative lack of caselaw addressing the interpretation to be given to the CISG's various provisions ${ }^{80}$ This is consistent with other studies that found that U.S. practitioners were likely to exclude the application of the CISG primarily because of their own lack of familiarity with its terms and the absence of a significant body of caselaw providing further guidance on its interpretation. ${ }^{81}$

\section{Addressing the UNIDROIT Principles in Contracts}

Most U.S. practitioners, $65 \%$, do not address the UNIDROIT Principles at all in their commercial contracts. ${ }^{82}$ Nevertheless, none of the U.S. practitioners, and only one of the foreign practitioners had ever argued against resorting to the UNIDROIT Principles when the parties' contractual documents were silent as to its application. ${ }^{83}$

Among U.S. practitioners who do address the Principles in their contracts, $15 \%$ choose to opt out, whereas $21 \%$ either specifically state their transactions should be interpreted in accordance with the UNIDROIT Principles as a whole or selectively invoke some portion of the Principles in their contractual documents. ${ }^{84}$ Foreign practitioners generally report greater use of the UNIDROIT Principles, with $45 \%$ incorporating some aspect of the Principles in their contracts, and only $9 \%$ specifically opting out of their coverage. However, again a large number of foreign practitioners, $45 \%$, do not address the UNIDROIT Principles in their contract documents at all. ${ }^{85}$

80. Appendix, Questions 13 and 45, infra.

81. See, e.g., Koehler, supra note 42, at 3-4.

82. These figures are based upon the 34 U.S. respondents who addressed the substance of this question. Another 45 U.S. survey participants said that this particular question was not applicable to their practice. See Appendix, Question 14 infra.

83. Appendix, Question 15, infra.

84. These figures are based upon the 34 U.S. respondents who addressed the substance of this question. Another 45 U.S. survey participants said that this particular question was not applicable to their practice. See Appendix, Question 14, infra.

85. These figures are based upon the 11 foreign respondents who addressed the substance of this question. Another 8 foreign survey participants said that this particular question was not applicable to their practice. See id. 


\section{Assessment of the Judiciary}

While practitioners reported relatively low levels of familiarity of regarding the CISG and the UNIDROIT Principles for themselves, ${ }^{86}$ their assessment of the judiciary's level of familiarity with these instruments was even lower.

Among those U.S. practitioners who litigate or arbitrate commercial disputes, no one characterized the judiciary as "thoroughly familiar" with these instruments, $72 \%$ felt the judiciary was "not at all familiar" with the CISG,${ }^{87}$ and $88 \%$ believed the judiciary was similarly unfamiliar with the UNIDROIT Principles. ${ }^{88}$ However, this is actually slightly less critical than the judiciary's own self-assessment of its familiarity with these instruments. ${ }^{89}$ Interestingly, while foreign practitioners identified a real reluctance on the part of the judiciary to apply the CISG or the UNIDROIT Principles to international commercial disputes once they were brought to the judge's attention, the U.S. practitioners in most of the target jurisdictions did not perceive this as an issue. ${ }^{90}$ However, in Florida, as well as in other U.S. jurisdictions that were not principally targeted by the survey, practitioners were generally equally split as to whether the judiciary was reluctant to apply these instruments to disputes once they were presented, with use of the UNIDROIT Principles being more problematic than the application of the CISG. ${ }^{91}$ One Florida practitioner noted that " $[\mathrm{b}]$ oth state court judges and most commercial litigators are simply unfamiliar with both the CISG and the UNIDROIT principles." 92

86. See supra notes 35-37 and accompanying text.

87. These figures are based upon the 18 U.S. respondents who addressed the substance of this question. Another 69 U.S. survey participants said that they did not have occasion to litigate or arbitrate international commercial disputes. See Appendix, Question 16, infra.

88. These figures are based upon the 8 U.S. respondents who addressed the substance of this question. Another 66 U.S. survey participants said that they did not have occasion to litigate or arbitrate international commercial disputes. See Appendix, Question 18, infra.

89. See supra notes $38-40$ and accompanying text.

90. See Appendix, Questions 17 and 19, infra.

91. See id.

92. Appendix, Question 45, infra, Response from Practitioners. 


\section{Survey Part III: Questions Addressed to the Judiciary}

There were very few responses from the judiciary, with only 17 judges participating in the survey. ${ }^{93}$ There are a number of possible reasons for the low response rate, not the least of which are the number of such requests judges periodically receive, the press of other more immediate business before the courts, or a reluctance to provide what some judges believed might appear to be advisory opinions. However, more pertinently, several jurists indicated that they declined to participate on the basis that they did not see cases involving these instruments, and therefore would have little to add to the survey. A staff member at the New York Court of Appeals strongly reiterated this view, suggesting that it might be more likely that the federal courts would see issues involving these instruments.

While this attitude might be surprising given the number of international transactions conducted in New York, not to mention the common border that state shares with Canada, it nevertheless again illustrates the pervasive misimpression of the role of the CISG in our legal system, as well as the judiciary's fundamental dependence upon practitioners to properly frame the issues brought before the courts. It also contrasts markedly with the comments offered by a state judge in Montana who wrote that, "[i]n a county that borders Canada, I need to know more about these principles. . . . Maybe I'll hear more on the subject and be prepared if I ever see the CISG and UNIDROIT mentioned again!"'94 If litigants fail to focus on the applicable law, and judges are unaware of the scope of these instruments themselves, courts may ultimately be left applying the wrong law to a case ${ }^{95}$ resulting in a potential misuse of judicial resources and a professional responsibility exposure for counsel. ${ }^{96}$

93. None of the judiciary in California, at either the state or federal level, participated in the survey. Appendix, Question 2, infra, Response from Judiciary.

94. Id. Response from the Judiciary. This is also a significantly different attitude than Professor Gordon encountered, where one Florida state judge responding to his survey said that he had no "printable" comments to offer other then he was "strongly opposed to world government." Gordon, supra note 3, at 369 n.30.

95. See, e.g., GPL Treatment, Ltd. v. Louisiana-Pacific Corp., 894 P.2d 470 (Or. Ct. App. 1995), $a f f$ 'd, 914 P.2d 682 (Or. 1996). This Oregon case involved litigation over the "merchant's exception" to Oregon's version of the UCC statute of frauds provision, UCC § 2-201, which the plaintiffs ultimately won after closely divided decisions by both the Oregon Court of Appeals and Supreme Court. The dissent to the Oregon Supreme Court's opinion noted, however, that the question of the applicability of the CISG to the dispute should have been addressed. 894 P.2d at 477 n.4 (Lesson, J., dissenting).

96. R. Brand, Professional Responsibility in a Transnational Transactions Practice: Must a Lawyer Involved in a Negotiation or Litigation of a Contract Matter Be Aware of the Sales Convention?, 17 J.L. 
Examining the responses that were received, however, shows that nearly $70 \%$ of those jurists participating in the survey had heard international commercial disputes in their courts. ${ }^{97}$ Even so, just two judges heard cases that mentioned the CISG,${ }^{98}$ and only one had dealt with the UNIDROIT Principles. ${ }^{99}$ In each instance where one of these instruments was considered, the deciding factor in its application appears to be whether the parties to the dispute specifically invoked either the CISG or the UNIDROIT Principles in their contractual documents. ${ }^{100}$ This further highlights the important role counsel plays in focusing the judiciary's attention on these instruments, both in drafting commercial agreements and in framing arguments in litigation.

The majority of the jurists participating in the survey said they did not have a basis for assessing the familiarity of the practicing bar in their jurisdiction with either the CISG or the UNIDROIT Principles. However, judges in Florida, Montana, and New York were split as to whether the practitioners in their jurisdictions were only "somewhat" or "not at all" familiar with these instruments, ${ }^{101}$ which is well below the practitioners own self-assessment of their knowledge of the CISG and the UNIDROIT Principles. ${ }^{102}$

\section{Survey Part IV: Questions Addressed to Law Professors}

The sixty-four law professors participating in the survey reported teaching a range of subjects and many, of course, teach multiple related courses. The vast majority of the respondents, $87 \%$, teach a basic Contracts course, and $41 \%$ teach a basic Sales course. Additionally, $36 \%$ teach advanced courses in

\& Сом. 301, 335-36 (1998). Professor Dodge notes that the plaintiffs in GPL Treatment apparently raised the issue of the applicability of the CISG, rather than the UCC, so late that the trial court ruled those arguments were waived. He writes,

[i]t is likely that the delay in raising the applicability of the CISG was attributable to the unfamiliarity of plaintiffs' counsel with the CISG. The result was that the plaintiffs gave up an argument that was a sure winner and were forced to rely instead upon the merchant's exception to the UCC statute of frauds, which presented a much closer question leading to two appeals and presumably costing the plaintiffs a good deal more in attorney's fees.

Dodge, supra note 3, at 75.

97. Appendix, Question 20, infra.

98. Appendix, Question 21, infra. This amounts to $17 \%$ of the 12 judges who addressed the substance of this question. See Appendix, Question 2, infra, Response from the Judiciary.

99. Appendix, Question 23, infra. This amounts to $9 \%$ of the 11 judges who responded to the substance of this question. See Appendix, Question 2, infra, Response from the Judiciary.

100. Appendix, Questions 22 and 24, infra. See also Appendix, Question 25, infra.

101. Appendix, Questions 26 and 27, infra.

102. See supra notes $35-37$ and accompanying text. 
International Business Transactions or related subjects, and $16 \%$ teach a dedicated course on the CISG or International Sales. ${ }^{103}$

\section{Covering the CISG or UNIDROIT Principles in Basic Contracts Courses}

Among the U.S. law professors teaching a basic Contracts course, a remarkable $78 \%$ address the CISG either alone or in conjunction with the UNIDROIT Principles. ${ }^{104}$ In doing so, $73 \%$ rely upon teaching materials found in a casebook, as opposed to preparing their own custom materials. ${ }^{105}$ Of those who do discuss the CISG, most, 54\%, only address the CISG "in passing," but $46 \%$ do incorporate detailed reference to at least portions of the CISG at various points in their Contracts courses. ${ }^{106}$ But, $83 \%$ of the U.S. law professors surveyed who address the UNIDROIT Principles in a basic Contracts course do so with only passing references. ${ }^{107}$

\section{Covering the CISG or UNIDROIT Principles in Basic Sales Courses}

Remarkably, $100 \%$ of the U.S. law professors teaching a basic Sales course address the CISG either alone or in conjunction with the UNIDROIT Principles. ${ }^{108}$ Again, the vast majority doing so, $88 \%$, rely upon teaching materials found in a casebook, as opposed to preparing their own custom materials. ${ }^{109}$ In Sales, in contrast to Contracts, however, 92\% incorporate

103. Appendix, Question 28, infra.

104. One participant, or $2 \%$ of the applicable responses, reported addressing the UNIDROIT Principles - but not the CISG - in a basic Contracts course. These figures are based upon the 50 U.S. law professors who addressed the substance of this question. Another 5 U.S. law professors said that they did not teach a basic Contracts course. See Appendix, Question 29, infra.

105. These figures are based upon the 38 U.S. law professors who addressed the substance of this question. Another 14 U.S. survey participants said that they do not discuss the CISG or UNIDROIT Principles in a basic Contracts course. In contrast, the foreign law professors all relied upon custom materials they prepare themselves. See Appendix, Question 30, infra.

106. These figures are based upon the 39 U.S. law professors who addressed the substance of this question. Another 13 U.S. survey participants said that they do not discuss the CISG in a basic Contracts course. SeeAppendix, Question 31, infra.

107. This figure is based upon the 24 U.S. law professors who addressed the substance of this question. Another 28 U.S. survey participants said that they do not discuss the UNIDROIT Principles in a basic Contracts course. See Appendix, Question 32, infra.

108. One participant, or $4 \%$ of the applicable responses, reported addressing the UNIDROIT Principles - but not the CISG - in a basic Sales course. These figures are based upon the 24 U.S. law professors who addressed the substance of this question. Another 27 U.S. survey participants said that they did not teach a basic Sales course. See Appendix, Question 33, infra.

109. These figures are based upon the 25 U.S. law professors who addressed the substance of this question. Another 19 U.S. survey participants said that they do not discuss the CISG or UNIDROIT 
detailed reference to at least portions of the CISG at various points in the course, with only $8 \%$ making a "passing" reference to the Convention. ${ }^{110} \mathrm{But}$ not unlike the minimal coverage given to the UNIDROIT Principles in Contracts, two-thirds of the professors only make "passing" reference to the Principles in their Sales courses. ${ }^{111}$

These figures suggest a substantial increase in the attention given by law school faculty to the CISG and UNIDROIT Principles over what Professor Gordon observed, ${ }^{112}$ even though the overall level of awareness among academics was unchanged. ${ }^{113}$ Moreover, formal coverage of the CISG and UNIDROIT Principles has recently improved in several casebooks, but their inclusion is by no means universal or comprehensive. ${ }^{114}$ Accordingly, it is also noteworthy that a decade ago none of the faculty reported addressing either of these instruments if they were not already included in the casebooks they were using with their courses, whereas in this survey only $26 \%$ of the U.S. professors teaching Contracts ${ }^{115}$ and $12 \%$ of those teaching Sales do so today

Principles in a basic Sales course. See Appendix, Question 34, infra.

110. These figures are based upon the 24 U.S. law professors who addressed the substance of this question. Another 21 U.S. survey participants said that they do not discuss the CISG in a basic Sales course. See Appendix, Question 35, infra.

111. This figure is based upon the 9 U.S. law professors who addressed the substance of this question. Another 34 U.S. survey participants said that they do not discuss the UNIDROIT Principles in a basic Sales course. See Appendix, Question 36, infra.

112. See Gordon, supra note 3, at 364-67. However, it is also likely that there is a degree of selfselection present among the law professors who chose to respond to these questions, which might inflate the apparent level of support for including these instruments in basic law school courses.

113. See supra notes 32-34 and accompanying text.

114. Compare Dodge, supra note 3, at 76-77, with Edward J. Murphy, Richard E. Speidel \& Ian Ayres, Studies In Contract Law (Foundation Press ed., 6th ed. 2003); Thomas D. Crandall \& Douglas J. Whaley, Cases, Problems, and Materials on Contracts (Aspen Publishers ed., 4th ed. 2004); Bruce W. Frier \& James J. White, The Modern Law of Contracts (Thomson West ed., $2 \mathrm{~d}$ ed. 2005); John Edwards Murray, Jr., Contracts: Cases and Materials (LexisNexis ed., 6th ed. 2006); David G. Epstein, Bruce A. Markell \& Lawrence Ponoroff, Making and Doing Deals: Contracts in Context (LexisNexis \& Matthew Bender eds., 2 d ed. 2006); Charles L. Knapp, Nathan M. Crystal \& Harry G. Prince, Problems in Contracts Law: Cases and Materials (Wolters Kluwer ed., Aspen Publishers 2007). The CISG now also features prominently in some Sales casebooks, such as KRISTEN David Adams, Commercial Transactions: A Survey of United States Law with International Perspective (Thomson West ed., 2007) and Bry an D. Hull, United States and International Sales, Lease, and Licensing Law: Cases And Problems (Wolters Kluwer ed., Aspen Publishers 2007). Additionally, another development has been the advent of casebooks specifically focused on the CISG such as John A. Spanogle \& Peter Winship, International Sales Law: A Problem Oriented Casebook (West Group ed., 2000), and J.F. Morrissey \& J.M. Graves, International Sales and Arbitration: Problems Cases And Commentary (forthcoming 2008).

115. These figures are based upon the 38 U.S. law professors who addressed the substance of this question. Another 14 U.S. survey participants said that they do not discuss the CISG or UNIDROIT Principles in a basic Contracts course. In contrast, the foreign law professors all relied upon custom 
using custom materials. ${ }^{116}$ This attests both to a greater level of interest on the part of individual faculty and the new availability of additional materials to augment existing casebooks. ${ }^{117}$

\section{Specific Topics Addressed in Basic Courses}

The law professors were also asked to identify, from a list of possible topics, what aspects of the CISG and the UNIDROIT Principles they address in these basic Contracts and Sales courses. As would be expected, this elicited a wide range of responses which are detailed in the Appendix. However, more than half of the respondents identified the following topics as among those they would choose to address regarding the CISG:

- basic scope, coverage and purpose of the CISG (Arts. 1, 2, 3 \& 6);

- contract formation and validity under the CISG (Art. 4);

- absence of a "parole evidence" rule under the CISG (Art. 8);

- lack of writing requirements and similar formalities under the CISG (Art. 11);

- offer and acceptance under the CISG (Art. 14);

- and "mirror image" and "last shot" rules under the CISG (Art. 19). ${ }^{118}$

In response to a similar question regarding the professors' coverage of topics related to the UNIDROIT Principles, there was much less consensus. Nevertheless, more than half of the respondents indicated they would address the impact and relationship of the UNIDROIT Principles to the CISG; and the basic scope, coverage, and purpose of the UNIDROIT Principles under the Preamble and Articles 1.4, 1.5, and 1.6. ${ }^{119}$

The professors who did not teach either the CISG or the UNIDROIT Principles in their basic Contracts or Sales courses said that their omission

materials they prepare themselves. See Appendix, Question 30, infra.

116. These figures are based upon the 25 U.S. law professors who addressed the substance of this question. Another 19 U.S. survey participants said that they do not discuss the CISG or UNIDROIT Principles in a basic Sales course. See Appendix, Question 34, infra.

117. Examples of the additional materials now available include Professor Dodge's excellent article, Teaching the CISG in Contracts, and the cases, teaching notes, and other materials posted on his faculty website. Dodge, supra note 3; Professor Dodge-Faculty Website, http://w3.uchastings.edu/dodge_01/ teaching_the_cisg.htm. Additionally, a more formal example of supplementary materials available in this area includes J.A. Spanogle, M.P. Malloy, L.F. Del Duca, K.A. Rowley \& A.K. Bjorklund, Global Issues in Contract Law (Thomson West, 2007) (book review).

118. See Appendix, Question 37, infra. In comments to this question, two participants also mentioned "risk of loss, exemption (Art. 79)" which is a significant topic. That topic was erroneously omitted from the final draft of Question 37, and the omission from the list may, in part, account for it not having been identified by more respondents. See id.

119. Appendix, Question 39, infra. 
was primarily due to the lack of time to cover these topics along with the other subjects the professors felt should be included in their courses. ${ }^{120}$ Secondary reasons included a preference that "international" courses cover these subjects and the professors' own lack of familiarity with the CISG or the Principles. ${ }^{121}$ The lack of teaching materials in the professors' preferred casebook was not an issue regarding the CISG, unlike what Professor Gordon found, but was seen as a definite issue with regard to the UNIDROIT Principles. ${ }^{122}$

\section{Assessment of the Bar and Judiciary}

U.S. law professors felt that $65 \%$ of the practicing bar in their jurisdiction was "somewhat" or "moderately" familiar with the CISG, ${ }^{123}$ and $32 \%$ would be similarly familiar with the UNIDROIT Principles. ${ }^{124}$ Thus, it appears that the law professors are a bit more generous in their opinion than the practitioners own self assessment, where $44 \%$ said they were "not at all familiar" with the CISG, ${ }^{125}$ but pretty close to the practitioners self-assessment regarding the UNIDROIT Principles where $63 \%$ of the bar said they were "not at all familiar" with the Principles. ${ }^{126}$ The U.S. law professors were even more generous in assessing the judiciary's familiarity with these instruments. The academics felt that $56 \%$ of the bench in their jurisdiction was "somewhat" or "moderately" familiar with the CISG, ${ }^{127}$ and $39 \%$ would be similarly familiar

120. "The importance of other topics that need to be covered" was cited by $72 \%$ of those who did not teach the CISG; and by $57 \%$ of those who did not address the UNIDROIT Principles in their courses. See Appendix, Questions 38 and 40, infra.

121. The "preference that "international' course cover these subjects" was cited by $22 \%$ of those who do not teach the CISG, and their own lack of familiarity was identified as a reason by $17 \%$ of those professors. Appendix, Question 38, infra. With regard to those professors who do not address the UNIDROIT Principles, only 17\% identified a "preference that 'international' course cover these subjects" as the reason while $46 \%$ cited their own lack of familiarity with the topic - making that reason second only to the time pressures faced in covering all the required material. Appendix, Question 40, infra.

122. At $31 \%$, the absence of suitable casebook materials was the third most cited reason for professors not addressing the UNIDROIT Principles in their courses. See Appendix, Questions 38 and 40, infra.

123. This figure is based upon the 28 U.S. law professors who addressed the substance of this question. An equal number, another 28 U.S. survey participants, said that they do not have occasion to form an opinion as to the bar's familiarity with the CISG. See Appendix, Question 41, infra.

124. This figure is based upon the 19 U.S. law professors who addressed the substance of this question. Another 36 U.S. survey participants said that they do not have occasion to form an opinion as to the bar's familiarity with the UNIDROIT Principles. See Appendix, Question 42, infra.

125. Appendix, Question 3, infra, Response from Practitioners.

126. Appendix, Question 4, infra, Response from Practitioners.

127. This figure is based upon the 18 U.S. law professors who addressed the substance of this question. Another 39 U.S. survey participants said that they do not have occasion to form an opinion as to 
with the UNIDROIT Principles. ${ }^{128}$ According to the judges own self assessment, $82 \%$ said they were "not at all familiar" with the CISG, ${ }^{129}$ and $88 \%$ of the bench said they were "not at all familiar" with the UNIDROIT Principles. ${ }^{130}$ Perhaps the professors have an unduly high opinion of the impact and effectiveness of their teaching in this area?

\section{Survey Part V: Comments}

The survey closed with an open end question soliciting further comments or observations. Most of the individual comments that pertain to particular subjects are incorporated into the other portions of this report. ${ }^{131}$

One consistent theme that appears out of the remaining comments, however, is the need and desire for further education on the CISG and UNIDROIT Principles, which was cited by commentators from each group; practitioners, jurists, and legal academics. ${ }^{132}$ Even so, three practitioners and one law professor, interestingly all from New York, offered comments arguably suggesting that they question whether there was much need to consider or learn about these instruments. Their comments also illustrate, yet again, the pervasive misconception of the CISG as something separate and apart from the body of U.S. contract law. The three practitioners wrote:

[1] I have just returned from a conference of European lawyers and I have attended three conference[s] of that group in the past year. I find it very interesting that I do not recall anyone mentioning these items, which may be an indication that they are of very limited application;

[2] Have not run into either CISG or UNIDROIT in my practice except for occasional choice of law clauses disclaiming their applicability; and,

[3] CISG and UNIDROIT are not covered in most traditional law school curricula. They may be accessed online if needed, and are taught in CLE programs and webinars. ${ }^{133}$

the judiciary's familiarity with the CISG. See Appendix, Question 43, infra.

128. This figure is based upon the 18 U.S. law professors who addressed the substance of this question. Another 38 U.S. survey participants said that they do not have occasion to form an opinion as to the bar's familiarity with the UNIDROIT Principles. See Appendix, Question 44, infra.

129. Question 3, infra, Response from the Judiciary.

130. Appendix, Question 4, infra, Response from the Judiciary.

131. See supra notes $43-44,74,92$ and accompanying text.

132. See Appendix, Question 45, infra.

133. It should also be noted that other practitioners from New York were strongly in favor of the need to learn more about these instruments. For example, another New York practitioner wrote, "[t]here needs to be much more education (CLE) for practitioners such as myself, who [practice] in the cross [border] contracts area but are almost totally unfamiliar with the CISG and UNIDROIT." Id. 
The New York law professor offered a more forceful statement:

I am reasonably confident that most American practitioners would prefer to blot the CISG out of their consciousness. If you are going to deal cross-border in a serious way you will need local counsel to advise you about the many features of the [other] country's laws that aren't governed by the CISG-e.g. bankruptcy, procedure for enforcement, security interests, etc. If you have local counsel anyway why bother with the CISG? ${ }^{134}$

Contrast these statements to comments received from yet another practitioner and law professor, from the other top exporting states, Florida and California. The Florida practitioner observed: "Business people and their attorneys need to understand that the CISG may apply unless they specifically exclude it. The word needs to get out." ${ }^{\prime 35}$ The California law professor offered an opinion on the value of these instruments from both an academic and practical perspective:

It is extremely important, I think, and I have been teaching students about the CISG and UNIDROIT Principles since their inception (and even before, since I've also talked about their predecessors) . . . that students be knowledgeable about these important areas of commercial practice. I also use these materials to teach students about applicable law and choice of law and other private international law doctrines that are too often overlooked in today's American law schools. I believe it is important that students learn even while 1-Ls that it is important to ask the PIL questions, to recognize that more than one law or set of laws might apply in a given case. Students need to internalize this insight early on, and not relegate it to the "exceptional" field of international law, which for many is simply not relevant to them (or so they think). ${ }^{136}$

\section{Concluding Observations}

It takes time for established practices to adapt and change; there is a "lag time" between the promulgation of non-mandatory legal rules and their widespread reception or use in practice. ${ }^{137}$ However, the CISG was incorporated into U.S. domestic law nearly twenty years ago, and the UNIDROIT Principles are now more than a decade old, and they are both still largely unknown and seldom seen in practice today. ${ }^{138}$

Many practitioners who are aware of these tools, nevertheless misconceive their impact and import. The CISG, in particular, continues to be

136. Id.

137. See Gordon, supra note 3 , at 365,374 .

138. See supra notes $35-45$ and accompanying text. 
adversely affected by a misimpression that it is "foreign" law, something distinct and separate from the law of contract applied here in the United States, and therefore can be ignored or dispensed with in favor of the more familiar rules of the common law and the UCC. ${ }^{139}$ As a consequence, the judiciary is even less familiar with these tools than are practitioners. ${ }^{140}$ Legal academics are becoming more attuned to the CISG and the UNIDROIT Principles and the issues they pose, but could do more to help educate the bench and bar. ${ }^{141}$

Taking a naive or cavalier approach to the CISG can be quite problematic. While the CISG is certainly part of the body of international or "foreign" law, as a ratified treaty it is also an integral part of contract law in the U.S. and by its own terms provides the default rules applicable to international transactions within its scope. One does not need to "opt in" to its coverage. ${ }^{142}$ This is not a trivial point. Just ten nations account for two-thirds of all trade in goods conducted by the United States. ${ }^{143}$ Eight of those ten are CISG contracting states, including both our NAFTA partners, Canada and Mexico, and our leading overseas trading partner, China. ${ }^{144}$ These three countries alone accounted for $\$ 1.2$ trillion out of a total $\$ 2.9$ trillion in U.S. trade in goods in 2006 , or over $40 \%$ of trade for the year. ${ }^{145}$ If the sorts of volumes generated by trade with the entire CISG membership, and the thousands upon thousands of transactions they represent, are extended back over the nearly twenty years the CISG has been in effect for the United States, it is beyond mind-boggling that the CISG only appears in as few as 56 reported U.S. cases. ${ }^{146}$ Given the low level of general awareness of the CISG, it is reasonable to assume that there are a significant number of commercial disputes where the CISG should apply, but where it is not being properly considered by either the bar or the bench.

139. See supra notes $70-79$ and accompanying text.

140. See supra notes $38-40$ and accompanying text.

141. See supra notes 32-34, 108-17 and accompanying text.

142. See supra notes 61-64 and accompanying text.

143. These figures are based upon 2006 figures, where the top ten trading partners accounted for $\$ 1.896$ trillion of the $\$ 2.892$ worth of trade in goods conducted that year. See U.S. Census Bureau, Foreign Trade Statistics, Top Trading Partners-Total Trade, Year to Date, December, 2006, http://www.census .gov/foreign-trade/statistics/highlights/top/top0612.html.

144. See id.

145. See id. In 2006 , total trade in goods with our number one trading partner, Canada, amounted to $\$ 534$ billion; with our second ranked trading partner, China, it amounted to $\$ 343$ billion; and with our third ranked trading partner, Mexico, it amounted to $\$ 332.4$ billion. Id.

146. See supra note 8 and accompanying text. 
Moreover, even the minority of practitioners who are aware of the Convention, but wish to opt out of its coverage, ${ }^{147}$ cannot blithely avoid the CISG altogether by simply using a choice of law clause. The effectiveness of a clause excluding the Convention depends upon whether a contract is actually formed, and whether the choice of law clause is among the terms of that contract. ${ }^{148}$ These are the issues that classically lie at the heart of the "battle of the forms," a problem that the common law, the UCC, and the CISG (along with the UNIDROIT Principles) all approach slightly differently, and consequently different results can be reached in any given case depending upon what properly is the applicable law. ${ }^{149}$ Accordingly, whether included as

147. See supra notes 70,71 and accompanying text.

148. In the international context, where each of the purported contracting parties may come from legal regimes with differing substantive laws, one might also add the problem of choosing the correct "conflict of laws" (or what is sometimes called "private international law") principles in order to help determine which party's substantive contract law might apply to resolve these questions. This can transform the "battle of the forms" into an almost circular problem - creating the sort of irreconcilable issues much beloved by legal academics teaching in this field-where the substantive law to be applied depends upon the choice of law, but where the choice of law may depend upon the applicable substantive law. The stated aims of the CISG included promoting the "adoption of uniform rules which govern contracts for the international sale of goods [which took] into account the different social, economic and legal systems [so as to] contribute to the removal of legal barriers in international trade," and thereby avoid or minimize the added complications introduced by differing substantive legal rules in such circumstances. See CISG, supra note 1, at Preamble. Whether the CISG's rules accomplish this aim in the context of the "battle of the forms" is debatable. See, e.g., Sukurs, supra note 3. See also Commentary on UN Convention on the InTERnAtional SALE OF Goods 232-45 (P. Schlectriem \& I. Schwenzer eds., 2d ed., Oxford 2005).

149. The Restatement summarizes the common law "mirror image" rule in $\S \S 39$ and 59. Restatement (SeCond) of Contracts $\S \S 39,59$. The UCC then rejected the common law "mirror image" rule, and its corollary the "last shot doctrine," regarding the terms of contracts formed when accepted by performance, in its battle of the forms provision:

Additional terms in acceptance or confirmation.

(1) A definite and seasonable expression of acceptance or a written confirmation which is sent within a reasonable time operates as an acceptance even though it states terms additional to or different from those offered or agreed upon, unless acceptance is expressly made conditional on assent to the additional or different terms.

(2) The additional terms are to be construed as proposals for addition to the contract. Between merchants such terms become part of the contract unless:

(a) the offer expressly limits acceptance to the terms of the offer;

(b) they materially alter it; or

(c) notification of objection to them has already been given or is given within a reasonable time after notice of them is received.

(3) Conduct by both parties which recognizes the existence of a contract is sufficient to establish a contract for sale although the writings of the parties do not otherwise establish a contract. In such case the terms of the particular contract consist of those terms on which the writings of the parties agree, together with any supplementary terms incorporated under any other provisions of this Act. UCC § 2-207.

When Article 2 was revised in 2003, the drafters continued to reject the common law approach and 
a routine part of a standard form, or in a custom contract, it is by no means certain that an attempt to "opt out" of the CISG's coverage with such a choice of law clause will be effective. ${ }^{150}$

Entirely apart from the effectiveness of such a clause, whether it is prudent to routinely attempt to opt out of the CISG's coverage is also debatable. The primary motivation for doing so appears to be a lack or familiarity with the CISG rather than a reasoned analysis of whether opting out serves particular client interests. ${ }^{151}$ This tendency towards what some describe as legal ethnocentricity ${ }^{152}$ is particularly striking given that the CISG not only provides the default rules for so many international transactions, but has come to serve as a model for the domestic commercial law in other nations with which we trade ${ }^{153}$ and is even applied in many cases to which it is not

specified in Revised UCC 2-206(3) that "[a] definite and seasonable expression of acceptance in a record operates as an acceptance even if it contains terms additional to or different from the offer," but altered the mechanism of 2-207 to remove any implicit preference for either the offeror's or offeree's form in such circumstances. The drafters of Revised Article 2 also specifically declined to take any position on how to handle the "terms in a box" problem which prompted Judge Easterbrook's rolling contract theory.

In contrast, the CISG, which also recognizes contract formation by conduct in Article 18, employs a variation of the approach found in the common law:

(1) A reply to an offer which purports to be an acceptance but contains additions, limitations or other modifications is a rejection of the offer and constitutes a counter-offer.

(2) However, a reply to an offer which purports to be an acceptance but contains additional or different terms which do not materially alter the terms of the offer constitutes an acceptance, unless the offeror, without undue delay, objects orally to the discrepancy or dispatches a notice to that effect. If he does not so object, the terms of the contract are the terms of the offer with the modifications contained in the acceptance.

(3) Additional or different terms relating, among other things, to the price, payment, quality and quantity of the goods, place and time of delivery, extent of one party's liability to the other or the settlement of disputes are considered to alter the terms of the offer materially.

CISG, supra note 1, Art. 19.

Finally, the UNIDROIT Principles mechanism, which similarly recognizes contract formation by conduct in Article 2.1.11, provides:

(1) A reply to an offer which purports to be an acceptance but contains additions, limitations or other modifications is a rejection of the offer and constitutes a counter-offer.

(2) However, a reply to an offer which purports to be an acceptance but contains additional or different terms which do not materially alter the terms of the offer constitutes an acceptance, unless the offeror, without undue delay, objects to the discrepancy. If the offeror does not object, the terms of the contract are the terms of the offer with the modifications contained in the acceptance.

UNIDROIT Principles, supra note 2, at Art. 2.1.11.

150. See, e.g., Sukurs, supra note 3, at 1484-92; Dodge, supra note 3, at 82-85. See also, e.g., Travelers Prop. Cas. Co., 474 F. Supp. 2d 1075 (D. Minn. 2007). But cf. Comerica Bank v. Whitehall Specialties, Inc., 352 F. Supp. 2d 1077 (C.D. Cal. 2004).

151. See supra notes $74-81$ and accompanying text.

152. See Cook, supra note 42, at 263.

153. For example, Koehler notes that the 2002 revision of Germany's Law of Obligations was largely based upon the CISG. See Koehler, supra note 42, at notes 15 and 16 and accompanying text. 
strictly applicable. Professor Albert Kritzer, the Executive Secretary of the Pace University Law School's Institute of International Commercial Law which hosts the Electronic Database on the CISG, notes that U.S. practitioners' tendency to automatically opt out of the CISG in cases where it would ordinarily apply stands in marked contrast to what is happening in China, our largest overseas trading partner. Professor Kritzer's study of the Chinese arbitration awards reported in the Pace database suggest that, in China, some parties or tribunals opt in to the CISG when it would not otherwise apply by its terms. ${ }^{154}$

Furthermore, ignoring the tools provided by the CISG does not necessarily guarantee the best outcome for a U.S. client. The CISG differs from the common law and the UCC in a number of areas, not only with regard to the "battle of the forms," but also in the absence of contract formalities such as those related to the statute of frauds or the parol evidence rule, the manner and timing of the effectiveness of communications, and in remedies which emphasize specific performance and measure damages in a different fashion, for instance. ${ }^{155}$

An example that helps highlight why an unthinking exclusion of the CISG might disadvantage a U.S. party is the CISG's absence of a perfect tender rule. If a U.S. seller in an international transaction relies upon UCC Article 2, instead of the CISG, the buyer may reject the delivery if it "fails in any respect," however minor, to conform to the contract. ${ }^{156}$ While the UCC may also provide the U.S. seller with an opportunity to cure the discrepancy, ${ }^{157}$ the

154. See Yang, CISG in China and Beyond, and The Application of the CISG the Current PRC Law and CIETAC Arbitration Practice, supra note 8.

155. Many of these differences are now being addressed in the various courses taught in law school. See supra notes 118-19 and accompanying text. See also Dodge, supra note 3. See generally supra note 114 and the referenced materials.

156. The UCC provision reads:

Buyer's Rights on Improper Delivery.

Subject to the provisions of this Article on breach in installment contracts (Section 2-612) and unless otherwise agreed under the sections on contractual limitations of remedy (Sections 2-718 and 2-719), if the goods or the tender of delivery fail in any respect to conform to the contract, the buyer may

- (a) reject the whole; or

- (b) accept the whole; or UCC $\$ 2-601$.

- (c) accept any commercial unit or units and reject the rest.

157. The UCC provision reads:

Cure by Seller of Improper Tender or Delivery; Replacement.

(1) Where any tender or delivery by the seller is rejected because non-conforming and the time for performance has not yet expired, the seller may seasonably notify the buyer of his intention 
buyer's rejection defeats or postpones contract formation and may create a host of interrelated problems regarding customs duties, letters of credit, third party obligations, etc. The CISG, in contrast, requires the buyer to accept and pay for the goods in such circumstances thereby forming a contract, ${ }^{158}$ albeit one that is subject to the buyer's claim for appropriate compensation, unless the seller's breach is fundamental to the transaction. ${ }^{159}$ Given the infinite variety of minor hiccups that can plague transactions conducted at a distance, and particularly in transborder dealings, it might well generally be more to the seller's advantage to use the default CISG rule rather than insisting upon the UCC, whether in a large custom contract or the seller's routine boilerplate agreements. ${ }^{160}$ Similarly, U.S. buyers (and sellers) may prefer relying upon CISG's broader rights to require specific performance and insist that contract obligations be completed, rather than looking to the common law and the UCC where specific performance is only available if the substitute remedy of

to cure and may then within the contract time make a conforming delivery.

(2) Where the buyer rejects a non-conforming tender which the seller had reasonable grounds to believe would be acceptable with or without money allowance the seller may if he seasonably notifies the buyer have a further reasonable time to substitute a conforming tender.

UCC $\S 2-508$.

158. The CISG provision reads:

(1) The buyer may declare the contract avoided:

(a) if the failure by the seller to perform any of his obligations under the contract or this

Convention amounts to a fundamental breach of contract[.]

CISG, supra note 1, Art. 49(1)(a).

The CISG has a similar provision that applies when the buyer is in breach, which reads:

(1) The seller may declare the contract avoided:

(a) if the failure by the buyer to perform any of his obligations under the contract or this Convention amounts to a fundamental breach of contract[.]

Id. at Art. 64(1)(a). Additionally, under the "Nachfrist" procedure, which was borrowed from German law, in the event of a non-fundamental breach the non-breaching party may set an additional reasonable time for the breaching party to perform. If performance is still not forthcoming, the contract may be avoided. See id. at Arts. 49(1)(b); 64(1)(b).

159. The CISG provides:

A breach of contract committed by one of the parties is fundamental if it results in such detriment to the other party as substantially to deprive him of what he is entitled to expect under the contract, unless the party in breach did not foresee, and a reasonable person of the same kind in the same circumstances would not have foreseen, such a result.

Id. at Art. 25.

160. The CISG approach has much in common with the common law doctrine of substantial performance. Dodge, supra note 3, at 91. Professor Dodge notes Karl Llewellyn's criticism of the perfect tender rule because of the possibilities it creates for opportunistic behavior by buyers in a falling commodities market, while pointing out that a substantial performance rule also creates the possibility of opportunistic behavior on the part of sellers. See id. and Karl Llewyelln, On Warranty of Quality, and Society, 37 Colum. L. Rev. 341, 378, 389 (1937). 


\section{monetary damages is inadequate. ${ }^{161}$ Accordingly, rather than acting on a}

161. The UCC provision on the availability of specific performance to buyers reads:

Buyer's Right to Specific Performance or Replevin.

(1) Specific performance may be decreed where the goods are unique or in other proper circumstances.

(2) The decree for specific performance may include such terms and conditions as to payment of the price, damages, or other relief as the court may deem just.

(3) The buyer has a right of replevin for goods identified to the contract if after reasonable effort he is unable to effect cover for such goods or the circumstances reasonably indicate that such effort will be unavailing or if the goods have been shipped under reservation and satisfaction of the security interest in them has been made or tendered.

UCC § 2-716.

This contrasts with the CISG provisions governing the rights afforded buyers which reads:

(1) The buyer may require performance by the seller of his obligations unless the buyer has resorted to a remedy which is inconsistent with this requirement.

(2) If the goods do not conform with the contract, the buyer may require delivery of substitute goods only if the lack of conformity constitutes a fundamental breach of contract and a request for substitute goods is made either in conjunction with notice given under article 39 or within a reasonable time thereafter.

(3) If the goods do not conform with the contract, the buyer may require the seller to remedy the lack of conformity by repair, unless this is unreasonable having regard to all the circumstances.

A request for repair must be made either in conjunction with notice given under article 39 or within a reasonable time thereafter.

CISG, supra note 1, Art. 46.

The equivalent provision in the UCC governing the seller's right to specific performance reads:

Action for the Price.

(1) When the buyer fails to pay the price as it becomes due the seller may recover, together with any incidental damages under the next section, the price

(a) of goods accepted or of conforming goods lost or damaged within a commercially reasonable time after risk of their loss has passed to the buyer; and

(b) of goods identified to the contract if the seller is unable after reasonable effort to resell them at a reasonable price or the circumstances reasonably indicate that such effort will be unavailing.

(2) Where the seller sues for the price he must hold for the buyer any goods which have been identified to the contract and are still in his control except that if resale becomes possible he may resell them at any time prior to the collection of the judgment. The net proceeds of any such resale must be credited to the buyer and payment of the judgment entitles him to any goods not resold.

(3) After the buyer has wrongfully rejected or revoked acceptance of the goods or has failed to make a payment due or has repudiated (Section 2-610), a seller who is held not entitled to the price under this section shall nevertheless be awarded damages for non-acceptance under the preceding section.

UCC $\S 2-709$.

Again this contrasts with the seller's rights under the CISG provision, which reads: "The seller may require the buyer to pay the price, take delivery or perform his other obligations, unless the seller has resorted to a remedy which is inconsistent with this requirement." CISG, supra note 1, Art. 62. It should be noted, however, that the CISG significantly limits the availability of specific performance when that remedy would be restricted under other national laws:

If, in accordance with the provisions of this Convention, one party is entitled to require performance 
simplistic desire to "blot out" the CISG from one's consciousness, ${ }^{162}$ an informed and rational determination is required as to what best serves the client's needs and interests. As Professor Ronald Brand notes, the failure to understand and properly apply the CISG in circumstances where the Convention applies is a clear violation of the requirement contained in the Model Rules of Professional Conduct that a lawyer possess and exercise "the legal knowledge, skill, thoroughness and preparation necessary for the representation" of a client, and therefore constitutes malpractice. ${ }^{163}$

Given our adversarial system, and the judiciary's dependence upon the bar to properly present the issues and the applicable law, it's not surprising that jurists are even less familiar with these instruments than are the practitioners. Nevertheless, the limited data available suggests that the judiciary is also affected by the persistent misimpression of the CISG as something separate and apart from U.S. law, and of concern only in occasional large custom transactions. ${ }^{164}$ In actuality, the Montana state court judge's intuitive sense that the CISG might be applicable to many smaller and routine cross-border commercial disputes is probably more correct, ${ }^{165}$ especially given the $\$ 860+$ billion annual trade conducted with our contiguous NAFTA partners $^{166}$ not to mention the countless small value individual goods transactions being concluded with trading partners around the world by both traditional means and at least partially over the Internet.

In contrast, the UNIDROIT Principles actually are separate and distinct from domestic law, and therefore it's not at all surprising that the Principles

of any obligation by the other party, a court is not bound to enter a judgment for specific performance unless the court would do so under its own law in respect of similar contracts of sale not governed by this Convention.

Id. at Art. 28. This provision does not actually mandate that courts looking to U.S. law deny specific performance, absent unique goods being at issue, but it does provide the basis for arguing that a refusal to grant specific performance would not violate the terms of the CISG. Alternatively, one might also argue that the CISG approach might be more advantageous to parties seeking specific performance in common law jurisdictions, if they simply specify the "proper circumstances" under which the remedy could be invoked. See Magellan International Corporation v. Salzgitter Handel GmbH, 76 F. Supp. 2 d 919 (N.D. Ill. 1999); see also Dodge, supra note 3, at 90.

162. See supra note 134 and accompanying text.

163. See Brand, supra note 96, at 335-36.

164. See supra notes $93-98$ and accompanying text.

165. See supra notes $93-94$ and accompanying text.

166. In 2006, total trade in goods with our number one trading partner, Canada, amounted to $\$ 534$ billion; and with our third ranked trading partner, Mexico, it amounted to $\$ 332.4$ billion. U.S. Census Bureau, Foreign Trade Statistics, Top Trading Partners-Total Trade, Exports, Imports, Year-to-Date December 2006, Total Trade (Goods), Total, All Trade, available at http://www.census.gov/foreigntrade/statistics/highlights/top/top0612.html. 
are even more seldom used by judges and practitioners than is the case with the CISG ${ }^{167}$ However, even though the Principles embody "soft law" and function best as a non-binding normative instrument that attempts to construct a single unified body of contract rules from a number of legal systems, they can be voluntarily invoked by the parties to any international transaction as is done with INCOTERMS ${ }^{168}$ or the $\mathrm{UCP}^{169}$ for example, although this occurs primarily in arbitration. ${ }^{170}$ In this manner, the Principles can serve practitioners and jurists alike as an international restatement of the law of contract. ${ }^{171}$ More work, however, needs to be done to identify and document their utility in that context. ${ }^{172}$

Legal academia has generally become much more aware of both the CISG and the UNIDROIT principles in the ten years since Professor Gordon conducted his survey. ${ }^{173}$ Materials addressing these instruments are more readily available, and they are being included by authors in casebooks even for first year courses. ${ }^{174}$ However, while more professors are including the CISG and the UNIDROIT Principles in their courses, it will take time for the students who are now being introduced to these instruments in law school to

167. See supra notes $35-40$ and accompanying text.

168. INCOTERMS are standard definitions of international commercial terms, such as FOB or CIF, published by the International Chamber of Commerce's Commission on Commercial Law and Practice. INCOTERMS are typically incorporated by reference in many international sale contracts. See International Chamber of Commerce, InCoterms 2000 (ICC Publication No. 560) 1999.

169. The UCP, or Uniform Customs and Practice for Documentary Credits, are privately formulated rules, derived from custom and usage, for handling letters of credit published by the International Chamber of Commerce. They are typically incorporated by reference in many international contracts. See International Chamber of Commerce, UCP 600 (ICC Publication No. 600) 2007.

170. See, e.g., Charles N. Brower \& Jeremy K. Sharpe, The Creeping Codification of Transnational Commercial Law: An Arbitrator's Perspective, 45 VA. J. INT'L L. 199 (2004); Fabrizio Marrella, Choice of Law in Third-Millennium Arbitrations: The Relevance of the UNIDROIT Principles of International Commercial Contracts, 36 Vand. J. TRANSNAT'L L. 1137 (2003).

171. See Michael J. Bonell, Soft Law and Party Autonomy: The Case of the UNIDROIT Principles, 51 Loy. L. ReV. 229 (2005).

172. Professor Bonell notes:

Parties wishing to have their contract governed by the UNIDROIT Principles refer to them as the sole lex contractus or in conjunction with a particular domestic law, which may have the role of supplementing the Principles in the case of gaps or, on the contrary, of being the law primarily governing the contract with the Principles relegated to a means of merely interpreting or supplementing it. Contrary to domestic courts, which are traditionally reluctant to grant parties the right to choose international principles and rules as the law governing the contract in lieu of a particular domestic law, arbitrators are generally permitted, at least in the context of international disputes, to base their decisions on soft law instruments such as the UNIDROIT Principles.

See Bonell, supra note 171, at 251-52.

173. See supra notes $32-34$ and accompanying text.

174. See supra notes $112-17$ and accompanying text. 
make an impact in practice and in the courts. Indeed, all of us in academia should be cautious about the success of these efforts, as it appears we are substantially overrating both the bench's and bars' own familiarity and comfort with these instruments. ${ }^{175}$

In sum, while the CISG and UNIDROIT Principles provide numerous concepts and rules that could be of use in serving client interests, they are being underutilized. Moreover, they are being underutilized not because of a conscious selection of a "better" rule or approach found in the common law or the UCC. Rather, they are being ignored either because of outright ignorance or because these instruments are simply unfamiliar and perceived - correctly (in the case of the UNIDROIT Principles) or quite incorrectly (in the case of the CISG) - as "foreign" law. The CISG is, and should be recognized as, the default law for a vast number international commercial transactions involving U.S. parties. The persistent failure to do so is neither professional nor good lawyering, and may well constitute malpractice. In the era of globalization, an era that international trade helped foster and create, legal ethnocentricity has no legitimate role. American lawyers, be they practitioners, jurists, or academics, need to be more aware of the CISG and the UNIDROIT Principles. 